University of Nebraska - Lincoln

DigitalCommons@University of Nebraska - Lincoln

USDA Forest Service / UNL Faculty Publications U.S. Department of Agriculture: Forest Service -National Agroforestry Center

2008

Recreation Visitor Attitudes Towards Management-ignited

Prescribed Fires in the Bob Marshall Wilderness Complex,

Montana

\author{
Katie Knotek \\ Aldo Leopold Wilderness Research Institute \\ Alan E. Watson \\ Aldo Leopold Wilderness Research Institute \\ William T. Borrie \\ University of Montana \\ Joshua G. Whitmore \\ Western Carolina University \\ David Turner \\ USDA Forest Service
}

Follow this and additional works at: https://digitalcommons.unl.edu/usdafsfacpub

Part of the Forest Sciences Commons

Knotek, Katie; Watson, Alan E.; Borrie, William T.; Whitmore, Joshua G.; and Turner, David, "Recreation Visitor Attitudes Towards Management-ignited Prescribed Fires in the Bob Marshall Wilderness Complex, Montana" (2008). USDA Forest Service / UNL Faculty Publications. 67.

https://digitalcommons.unl.edu/usdafsfacpub/67

This Article is brought to you for free and open access by the U.S. Department of Agriculture: Forest Service -National Agroforestry Center at DigitalCommons@University of Nebraska - Lincoln. It has been accepted for inclusion in USDA Forest Service / UNL Faculty Publications by an authorized administrator of DigitalCommons@University of Nebraska - Lincoln. 


\title{
Recreation Visitor Attitudes Towards Management-ignited Prescribed Fires in the Bob Marshall Wilderness Complex, Montana
}

\author{
Katie Knotek ${ }^{1}$ \\ Aldo Leopold Wilderness Research Institute \\ Rocky Mountain Research Station, USDA Forest Service \\ Alan E. Watson ${ }^{1}$ \\ Aldo Leopold Wilderness Research Institute \\ Rocky Mountain Research Station, USDA Forest Service \\ William T. Borrie ${ }^{2}$ \\ College of Forestry and Conservation \\ The University of Montana \\ Joshua G. Whitmore ${ }^{3}$ \\ Base Camp Cullowhee \\ Western Carolina University \\ David Turner ${ }^{1}$ \\ Rocky Mountain Research Station, USDA Forest Service
}

1. Rocky Mountain Research Station, USDA Forest Service, 790 E. Beckwith Ave., Missoula, MT, U.S.A. 59801

2. College of Forestry and Conservation, The University of Montana, Missoula, MT, U.S.A. 59812.

3. Base Camp Cullowhee, Western Carolina University, A.K. Hinds University Center, Cullowhee, NC, U.S.A. 28723.

This research was part of a larger trend study assessing visitor characteristics, attitudes, and use patterns in the Bob Marshall Wilderness Complex. We gratefully acknowledge scholarly reviews by Dr. Jerry J. Vaske and Dr. David J. Parsons in preparation of the manuscript. Funding was provided by the USDA Forest Service National Fire Plan and the Lolo and Flathead National Forests.

Address correspondence to: Alan Watson, Aldo Leopold Wilderness Research Institute, Missoula, MT, U.S.A. 59801. Phone: (406) 542-4197. Email: awatson@fs.fed.us. 


\begin{abstract}
Research at the Bob Marshall Wilderness Complex in Montana explored differences in recreation visitors' attitudes towards the use of management-ignited prescribed fires in the wilderness. A mail-back survey of visitors $(n=291)$ during the 2004 season revealed that over half of visitors would accept prescribed fires in wilderness. This support did not vary by ignition purpose: (a) to restore the natural role of fire or (b) to reduce hazardous fuels and potential for fire escaping to non-wilderness lands. Local visitors, however, were significantly more accepting of prescribed fires than non-local visitors across both ignition purposes. A smaller proportion of visitors than was expected considered the presence of natural fire undesirable.
\end{abstract}

KEYWORDS: Prescribed fire, recreation, restoration, social judgment, wilderness

Introduction

In the early to mid-1900s, USDA Forest Service (USFS) fire policy focused on fire suppression and control, guiding decisions to extinguish all fires as soon as possible after detection. In 1971, however, USFS fire suppression policy was modified for wilderness areas, allowing fire ignited naturally by lightning to burn under prescribed conditions. The first of these "prescribed natural fires" (currently recognized in policy as "wildland fire use fires") on USFS land occurred in the Selway-Bitterroot Wilderness in 1972 (Parsons \& Landres, 1998). Later, an official change in USFS fire policy (USDA FS, 1978) recognized the use of wildland fire as a land management tool with potential resource benefits across USFS lands. This policy change made it possible for lightning-ignited fires, as well as management-ignited fires, to burn under prescribed conditions on more of the federal land base. However, the use of fire within wilderness remained limited to lightning-ignited fires until further policy revision in 1985 (USDA FS, 1985).

The social and ecological complexity of implementing management-ignited fires (now recognized in policy as "prescribed fires") in wilderness has received recent attention in the literature. For example, although prescribed fires in wilderness are allowed under certain conditions, Parsons (2000) suggests they are often viewed as inappropriate human manipulations that detract from the wild or untrammeled character of wilderness. At the same time, there is increasing recognition of the ecological importance of prescribed fires when used as a management tool to restore and maintain natural conditions in wilderness (Parsons \& Landres, 1998). Thus, the use of prescribed fires in wilderness is a management dilemma that involves tradeoffs between seemingly competing wilderness values, such as naturalness and wildness (Landres, Brunson, Merigliano, Sydoriak, \& Morton, 2000). Non-wilderness concerns must also be considered by managers that include threats to private property, infrastructure, and timber of commercial value at the interface between wild lands and urban areas (Shindler, 2007).

The shift from total suppression to use of wildland fire in wilderness created a need for knowledge about the public's attitudes towards wilderness fire management on USFS lands (e.g., Love \& Watson, 1992; Lucas, 1980; Lucas, 1985; Watson, Hendee, \& Zaglauer, 1996). A number of studies of recreation visitors to the Selway-Bitterroot Wilderness examined attitudes towards potential use of management-ignited fires in wilderness. Stankey (1976) found in 1971 that suppression policies were highly 
acceptable to the visitors sampled, with higher levels of knowledge about the role of fire in the ecosystem being related to acceptance of fires to burn in wilderness. In a later Selway-Bitterroot Wilderness visitor study, McCool \& Stankey (1986) then found rising levels of visitor knowledge about the role of fire and a correlation of that knowledge with increasing acceptance of the policy to allow fire use in wilderness. Nearly half of the 1984 sample of visitors believed that management-ignited fires would be beneficial. In an open-ended follow-up question, visitors perceived benefits such as reduced fire hazards, improved wildlife habitat and restoration of fire to its natural role. A similar trend study of visitors to the Bob Marshall Wilderness Complex found the proportion of visitors who indicated that natural forest fires were desirable increased from 26\% in 1970 to 49\% in 1982 (Stankey, 1976; McCool \& Stankey, 1986).

The purpose of this current research note is to further our understanding of recreation visitor attitudes towards prescribed fires in wilderness using data collected in the Bob Marshall Wilderness Complex. This 2004 study was conducted primarily to replicate previous visitor studies in the Bob Marshall Wilderness Complex (Lucas, 1980; Lucas, 1985), but it also incorporated an analysis of visitors' attitudes towards prescribed fires in the wilderness following the approach McCool and Stankey (1986) had used to understand visitors' attitudes towards natural fires in wilderness. Of particular interest is to understand if visitors support prescribed fire, why they support it and if local, potentially more knowledgeable, visitors were more supportive of prescribed fire in wilderness than non-local visitors.

\section{Methods}

Data for this study were obtained from a mail-back survey sent to individuals who had visited the Bob Marshall Wilderness Complex between June 18 and October 18, 2004. A larger Bob Marshall Wilderness Complex study to assess trends in visitor characteristics, attitudes, and use patterns between 1970 (Lucas, 1980), 1982 (Lucas, 1985), and 2004 (Whitmore, Borrie, \& Watson, 2004) provided this opportunity to explore how visitors viewed some aspects of wildland fire policy not previously studied.

The study population consisted of adults 16 years or older who visited the Bob Marshall Wilderness Complex during the summer and fall of 2004. Sampling occurred at the 13 most visited trailheads following sampling plans as used in previous studies at this wilderness. Trailheads were sampled for four-day blocks of time during weekdays (Monday - Thursday) and three-day blocks of time over weekends (Friday - Sunday). Fieldworkers contacted visitors upon entry and exit at trailheads during six hour periods between 8:00 a.m. and 8:00 p.m. Visitor information was collected on whether they used an outfitter, length of stay, mode of travel, education level, and previous experience level at the Bob Marshall Wilderness Complex. Each trailhead was sampled with a probability proportional to size, meaning that among the 13 trailheads included in the study, those with higher levels of use were sampled more frequently than those with lower levels of use. This bias towards higher use trailheads was accounted for in analysis by weighting data inversely proportional to the sample size (data from lower use trailheads were weighted more than data from higher use trailheads). A total of 408 visitors were contacted on site; 12 visitors refused to participate, ultimately providing 396 usable names and addresses. 


\section{Mail Survey Administration}

An initial mailing was sent to visitors within 12 days of initial contact. A postcard reminder was mailed to non-respondents three to four weeks after the initial mailing. The mail survey was returned by 294 respondents; three surveys were returned "undeliverable." This yielded an overall sample size of 291 for a $72 \%$ response rate.

A non-response bias check was conducted on six key variables measured in the initial contact on-site, including season of use, use of outfitter, length of stay, mode of travel, education level, and previous experience in the Bob Marshall Wilderness Complex. No significant differences (independent samples t-test, with an alpha level of .10 as used for all statistical tests throughout this note) were found between respondents and non-respondents.

\section{Attitude Measures}

Respondents' attitudes toward wilderness prescribed fires were measured using a response method based on the Social Judgment Approach (Sherif, Sherif, \& Nebergall, 1965), which suggests that attitudes are comprised of a range of feelings rather than a single, absolute opinion. This approach was used in the Selway-Bitterroot Wilderness trend studies (McCool \& Stankey, 1986; Stankey, 1976) to determine the range of wilderness fire suppression policies that visitors judged acceptable. Building upon this research, the current study presented nine different evaluative statements regarding management-ignited prescribed fires in the Bob Marshall Wilderness Complex (Table 1). The policy statements ranged from one extreme that "It is absolutely necessary that prescribed fires are ignited by wilderness managers," to the other extreme that "It is absolutely necessary that prescribed fires are not ignited by wilderness managers." The intermediate items (3 increasingly less permissive and 3 increasingly less restrictive) progressed from each anchor towards a neutral policy at the center: "It is hard to decide whether or not prescribed fires should be ignited by wilderness managers." In addition, the evaluative statements were posed twice, once each for two potential purposes of management-ignited fires in wilderness: (a) to restore the natural role of fire within the wilderness, and (b) to reduce hazardous fuels and lessen the threat of wildfire escaping the wilderness. Respondents placed a check ("V") in front of the one policy statement that was closest to their own personal feeling and a circle ("O") in front of all other statements that were also acceptable to them. The attitude measures provided visitors' range of acceptability of wilderness prescribed fires for the different ignition purposes. In its simplest form, each potential policy was rated as acceptable or not acceptable.

Also, similar to past studies of wilderness visitors in the Bob Marshall Wilderness Complex (Lucas, 1980; Lucas, 1985), one survey item was used to measure the desirability/undesirability of "natural forest fires started by lightning" using the following response categories: undesirable; don't care; desirable; and desirable in more heavily used parts of wilderness, but not in more lightly used parts. Only the "undesirable" and "desirable" response categories are reported in this manuscript for comparison to results from the past Bob Marshall Wilderness Complex studies. 
TABLE 1

Evaluative Statements Regarding Management-ignited Prescribed Fires in the Bob Marshall Wilderness Complex, Acceptability Averaged Across Ignition Purposes, for All Respondents

\begin{tabular}{|c|c|c|}
\hline \multicolumn{2}{|c|}{ Evaluative Statement } & \multirow{2}{*}{$\begin{array}{c}\begin{array}{c}\text { Estimated } \\
\text { LS-Mean }^{\mathrm{a}}\end{array} \\
0.34 \mathrm{~B}\end{array}$} \\
\hline 1. & $\begin{array}{l}\text { It is absolutely necessary that prescribed fires are ignited by } \\
\text { wilderness managers ... }\end{array}$ & \\
\hline 2. & $\begin{array}{l}\text { It would probably be best if prescribed fires are ignited by wil- } \\
\text { derness managers ... }\end{array}$ & $0.52 \mathrm{D}$ \\
\hline 3. & $\begin{array}{l}\text { Generally, it would be preferable if prescribed fires are ignited by } \\
\text { wilderness managers ... }\end{array}$ & $0.54 \mathrm{D}$ \\
\hline 4. & $\begin{array}{l}\text { It is hard to decide what the policy toward prescribed fires in wil- } \\
\text { derness should be, but probably managers should ignite them ... }\end{array}$ & $0.53 \mathrm{D}$ \\
\hline 5. & $\begin{array}{l}\text { It is hard to decide whether or not prescribed fires should be } \\
\text { ignited by wilderness managers. }\end{array}$ & $0.48 \mathrm{CD}$ \\
\hline 6. & $\begin{array}{l}\text { It is hard to decide what the policy toward prescribed fires in the } \\
\text { wilderness should be, but managers probably should not ignite } \\
\text { them ... }\end{array}$ & $0.38 \mathrm{~B}$ \\
\hline 7. & $\begin{array}{l}\text { Generally, it would be preferable if prescribed fires are not } \\
\text { ignited by wilderness managers ... }\end{array}$ & $0.39 \mathrm{BC}$ \\
\hline 8. & $\begin{array}{l}\text { It would probably be best if prescribed fires are not ignited by } \\
\text { wilderness managers ... }\end{array}$ & $0.36 \mathrm{~B}$ \\
\hline 9. & $\begin{array}{l}\text { It is absolutely necessary that prescribed fires are not ignited by } \\
\text { wilderness managers ... }\end{array}$ & $0.22 \mathrm{~A}$ \\
\hline
\end{tabular}

Note. Each statement was posed in relation to two potential ignition purposes of prescribed fires in the wilderness: 1) ... to restore the natural role of fire within the wilderness, and 2) ... to reduce hazardous fuels and lessen the threat of wildfire escaping the wilderness. Respondents were asked to place a check (" $\sqrt{ }$ ") in front of the one statement which was closest to their own personal feeling and a circle ("O") in front of all other statements which were also acceptable to them.

a Scale rating for the acceptability of evaluative statements ranged from $0=$ "not acceptable" to $1=$ "acceptable." TukeyKramer grouping for evaluative statement least squares (LS) means. LS-means followed by the same letter are not significantly different (alpha level of .10).

\section{Visitor Segmentation}

Respondents were segmented into two groups (local and non-local visitors) to assess differences in visitors' attitudes towards wilderness prescribed fires based on regional residence, as hypothesized from previous research findings that suggest knowledge is greater and therefore less restrictive fire policies are supported by more local residents (Manfredo, Fishbein, Haas, and Watson, 1990). Since "local" has not clearly been defined in the literature, this study focused on very local communities. The "local" visitor group included all respondents who reported residence within one of the seven counties immediately surrounding the Bob Marshall Wilderness Complex (Flathead, Lake, Lewis and Clark, Missoula, Pondera, Powell, and Teton Counties). The "non-local" visitor group included all respondents with a Montana residence outside these seven 
counties or with an out-of-state residence. There were slightly more non-local visitors $(56 \%, n=162)$ than local visitors $(44 \%, n=129)$.

\section{Data Analysis}

The range of wilderness prescribed fire policies that visitors judged acceptable was described by calculating a proportion of acceptability rating across the different ignition purposes for both local and non-local visitors (presented as a decimal to the hundredths place). An acceptability value of " 1 " was given to an individual if he or she marked an evaluative statement as closest to his or her own personal feeling or as also acceptable. An acceptability value of " 0 " was given to an individual if he or she did not mark the evaluative statement as either closest to his or her own personal feeling or also acceptable. The data were collected and hence analyzed as a post-stratified completely randomized mixed model (residence type (local vs. non-local) with doubly repeated measurements (nine evaluative statements for each of two ignition purposes). This allows investigation of three factors (residence, ignition purpose and evaluative statement), as well as all 2- and 3-way interactions. Because the responses to each evaluative statement were zeroes and ones, a logistic model for the proportion agreeing with each evaluative statement was fit using PROC GLIMMIX (SAS).

\section{Results}

The test for differences among evaluative statements was significant, $F(8,4797)=$ 20.18, $p<.01$ (Table 2). Statements 2, 3, and 4 had the highest level of acceptance, averaged across purposes, with just over $50 \%$ of respondents indicating they could accept some prescribed burning in wilderness (Table 1). Statement 5 , the undecided option, was acceptable to about $48 \%$ of respondents; not significantly different from

TABLE 2

Multivariate Tests of Main and Interaction Effects of Evaluative Statement ${ }^{a}$, Ignition Purpose ${ }^{b}$, and Residence Type

\begin{tabular}{lcccc}
\hline Effect & $\begin{array}{c}\text { Numerator } \\
d f\end{array}$ & $\begin{array}{c}\text { Denominator } \\
d f\end{array}$ & $F$ Value & $p$ Value \\
\hline Residual & 1 & 236 & 3.52 & 0.06 \\
Ignition Purpose & 1 & 4797 & 2.85 & 0.09 \\
Ignition Purpose x Residence type & 1 & 4797 & 0.00 & 0.95 \\
Evaluative Statement & 8 & 4797 & 20.18 & $<0.01$ \\
Evaluative Statement x Residence type & 8 & 4797 & 4.92 & $<0.01$ \\
Ignition Purpose x Evaluative Statement & 8 & 4797 & 0.03 & 1.00 \\
$\begin{array}{l}\text { Ignition Purpose x Evaluative Statement } \\
\text { x Residence type }\end{array}$ & 8 & 4797 & 0.23 & 0.99 \\
\hline
\end{tabular}

Note. Results based on the GLIMMIX ANOVA.

${ }^{a}$ Evaluative statements are listed in Table 1.

${ }^{\mathrm{b}}$ Two prescribed fire ignition purposes were evaluated: 1) ... to restore the natural role of fire within the wilderness, and 2) ... to reduce hazardous fuels and lessen the threat of wildfire escaping the wilderness.

${ }^{c}$ Visitors were segmented into two categories based on residence: 1) local, and 2) non-local. 
statements 2, 3 and 4. Statements 6,7 and 8, the more restrictive policy statements, are significantly less acceptable $(36-38 \%)$ than statements 2,3 and $4(p<0.01)$. Interestingly, the averages of the more restrictive statements (6, 7 and 8$)$ were not significantly more acceptable than the "always burn" statement (1). The "never burn" statement (9), however, was the least acceptable (22\%) and was significantly lower than all the other statements.

The only significant interaction found was between the evaluative statements and residence type (local/non-local), $F(8,4797)=4.92, p<.01$ (Table 2). Figures 1 and 2 illustrate generally positive support of prescribed fire, but no differences in acceptance patterns across purposes for both local and non-local visitors. However, Figure 3 illustrates the interaction effect with different patterns of response for local and non-local visitors when responses to evaluation statements for the two purposes are combined through averaging.

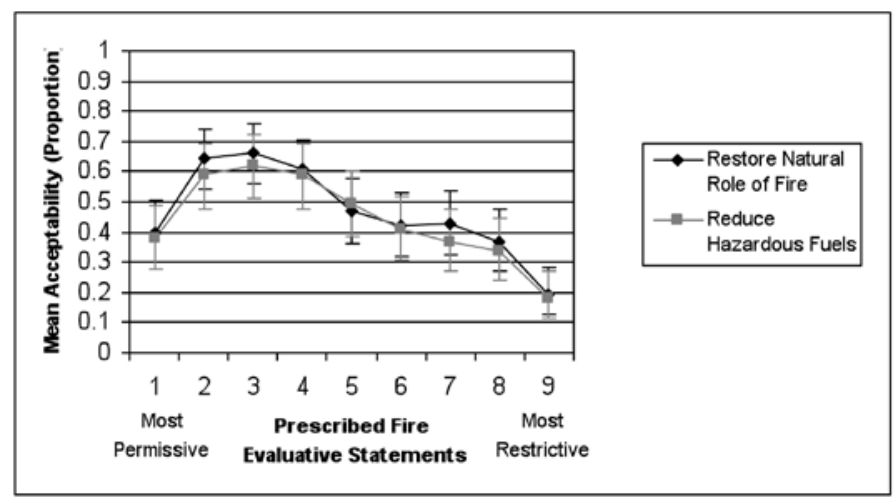

Figure 1. Local visitors' proportional acceptability ratings of prescribed fire evaluative statements by ignition purpose.

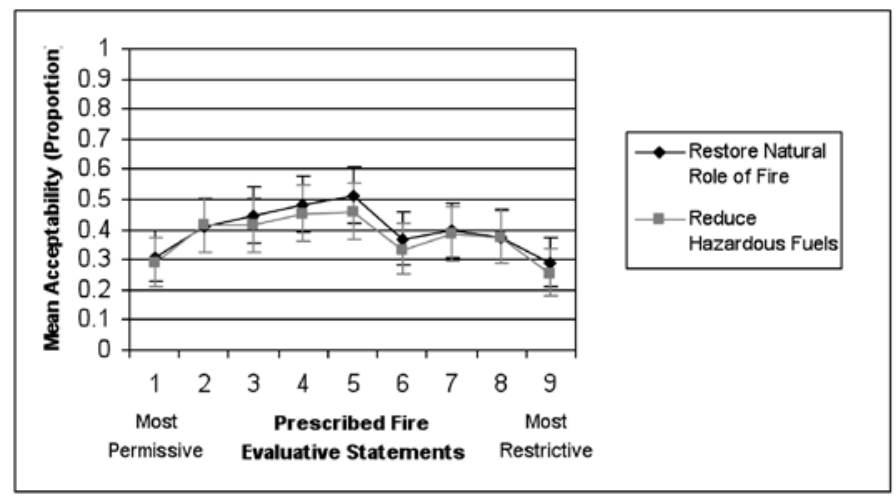

Figure 2. Non-local visitors' proportional acceptability ratings of prescribed fire evaluative statements by ignition purpose. 


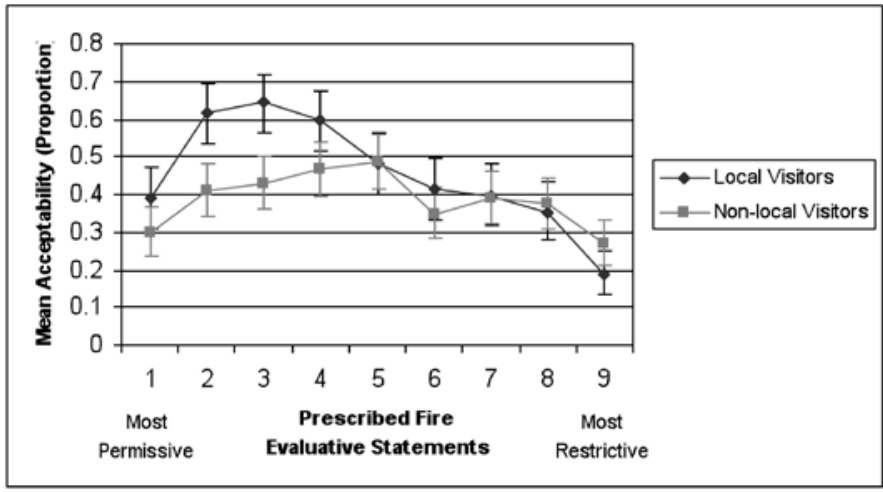

Figure 3. Proportional acceptability ratings of prescribed fire evaluative statements by residence type.

TABLE 3

Simple Effect Comparisons: Mean Differences in Acceptability Ratings of Prescribed Fire Evaluative Statements Between Local and Non-local Visitors

\begin{tabular}{lcccc}
\hline Evaluative Statement & Local Visitors & $\begin{array}{c}\text { Non-local } \\
\text { Visitors }\end{array}$ & $t$ Value & $p$ Value \\
\hline $1 . \mathrm{c}$ & 0.39 & 0.30 & 1.74 & 0.08 \\
2. & 0.62 & 0.41 & 3.67 & $<0.01$ \\
3. & 0.64 & 0.43 & 3.80 & $<0.01$ \\
4. & 0.60 & 0.47 & 2.32 & 0.02 \\
5. & 0.48 & 0.49 & -0.10 & 0.92 \\
6. & 0.41 & 0.35 & 1.21 & 0.23 \\
7. & 0.40 & 0.39 & 0.15 & 0.88 \\
8. & 0.35 & 0.37 & -0.41 & 0.68 \\
9. & 0.19 & 0.27 & -1.88 & 0.06 \\
\hline
\end{tabular}

Note. Means are calculated in proportions and represent data for both ignition purposes.

${ }^{a}$ Scale rating for the acceptability of evaluative statements ranged from $0=$ "not acceptable" to $1=$ "acceptable." ${ }^{\mathrm{b}} p$ values are adjusted using Tukey's Honestly Significant Difference.

${ }^{c}$ Evaluative statements are listed in Table 1.

To further examine the two-way interaction between evaluative statement and residence type, nine simple effect comparisons were made (Table 3). Results showed significant differences between local and non-local visitors in acceptability of five of the nine evaluative statements. At an alpha level of 0.10 , local visitors produced significantly higher acceptability ratings than non-local visitors for statements 1 through 4 (more permissive); there are no significant differences for statements 5 through 8 (more restrictive); and non-local visitors had higher acceptability ratings than locals for statement 9 (the most restrictive). 
From a separate set of survey items within the questionnaire, it was found that two-thirds of visitors $(n=186)$ indicated natural fire ignitions in wilderness were desirable, with only $12 \%(n=34)$ considering them undesirable. This support level, interestingly, was much higher than the $49 \%$ found in a comparable assessment at the same wilderness in 2003, a year of extremely high fire intensity and frequency in the Bob Marshall Wilderness Complex (Borrie, McCool, \& Whitmore, 2006). This 2004 study also found many other visitor attitudes toward fire and fire management quite different between the "high" fire year and the "lower" fire year.

\section{Discussion and Conclusions}

To date, the attitudes of recreation visitors towards wilderness prescribed fires have been explored very little; rather research has focused primarily on demonstrating strengthening visitors' acceptance of lightning-ignitions. However, it appears visitors' feelings towards the prescribed fire issue are variable, with slightly more support for prescribed fire in wilderness than opposition. While some managers and some conservation groups oppose prescribed fires in wilderness, this sample of the public was relatively supportive.

For this sample of wilderness recreation visitors, there do not seem to be differences in acceptance of prescribed fires based on whether the purpose of ignition is to restore the natural role of fire within the wilderness or to reduce hazardous fuels and lessen the threat of wildfire escaping the wilderness. Evidently wild land fire use for wilderness purposes is at least as important as non-wilderness purposes to visitors. It does appear that local visitors accept prescribed fires in wilderness more than nonlocal visitors, and this is consistent with previous findings regarding fire use policies, and may be due to a better understanding of fire effects by more local residents, as suggested by Manfredo, Fishbein, Haas, and Watson (1990) and Shindler (2007).

We are concerned that the Social Judgment Approach to scale development and measurement of these recreation visitors' attitudes is exerting some force on their responses. Visitors were asked to respond to two sets of questions, differing in the stated purpose of igniting prescribed fires in the wilderness, and both sets were visually and cognitively complex. In a previous examination of the generalizability of social judgment scales, Williams, Roggenbuck, Patterson, and Watson (1992) noted variability in judgments about social impacts using different survey methods. They found that visitor standards determined from a mail-back survey were more restrictive than standards determined from an on-site survey among the same population for the same potential policy questions. Thus, if consistent with previous social judgment methods research, data obtained for our analysis may be more negative toward management use of prescribed fire than if the data had been collected during visits or immediately following visits on site. The occurrence of a "high" fire year (2003) immediately prior to this study could also have influenced visitors' responses in a more restrictive direction, particularly those of local visitors who were likely more aware of the previous years' fires.

The goal of wilderness fire management is to restore or maintain the natural role of fire in as many places as possible (Aplet, 2006). Thus, there is a need to continue to develop understanding of public attitudes toward prescribed fires in wilderness. Although public opinion, whether local or national, is not the sole consideration in 
establishing wilderness fire policy, managers should be more aware of how different stakeholders respond to potential restoration tools, such as management-ignited prescribed fire. We suggest that future research needs to expand beyond a focus on just recreation visitors' attitudes toward wilderness fire management. Very seldom in the past have scientists considered the attitudes of other stakeholders toward wilderness fire management. Including subsistence users of federal lands and providing more focus on local community members, past visitors, distant non-visitors, and other interested parties (e.g., politicians, commercial service providers, scientists, and educators) in future studies will likely broaden our understanding of the barriers and opportunities related to the role of fire in wilderness.

\section{References}

Aplet, G. H. (2006). Evolution of wilderness fire policy. International fournal of Wilderness, 12(1), 9-13.

Borrie, W. T., McCool, S. F., \& Whitmore, J. G. (2006). Wildland fire effects on visits and visitors to the Bob Marshall Wilderness Complex. International Fournal of Wilderness, 12(1), 32-35, 38.

Landres, P., Brunson, M. W., Merigliano, L., Sydoriak, C., \& Morton, S. (2000). Naturalness and wildness: The dilemma and irony of managing wilderness. In D. N. Cole, S. F. McCool, W. T. Borrie, \& J. O'Loughlin (Comps.), Wilderness Science in a Time of Change Conference, Volume 5: Wilderness ecosystems, threats, and management (pp. 377-81). Proceedings RMRS-P-15-Vol-5. Ogden, UT: U.S. Department of Agriculture, Forest Service, Rocky Mountain Research Station.

Love, T. G., \& Watson, A. E. (1992). Effects of the Gates Park Fire on recreation choices. (Research Note INT-402). Ogden, UT: U.S. Department of Agriculture, Forest Service, Intermountain Research Station.

Lucas, R. C. (1980). Use patterns and visitor characteristics, attitudes and preferences in nine wilderness and other roadless areas. (Research Paper INT-253). Ogden, UT: U.S. Department of Agriculture, Forest Service, Intermountain Research Station.

Lucas, R. C. (1985). Visitor characteristics, attitudes, and use patterns in the Bob Marshall Wilderness Complex. (Research Paper INT-345). Ogden, UT: U.S. Department of Agriculture, Forest Service, Intermountain Research Station.

Manfedo, M. J., Fishbein, M., Haas, G. E., \& Watson, A. E. (1990). Attitudes toward prescribed fire policies: The public is widely divided in its support. Fournal of Forestry, 99(7), 19-23.

McCool, S. F., \& Stankey, G. H. (1986). Visitor attitudes toward wilderness fire management policy 1971-84. (Research Paper INT-357). Ogden, UT: U.S. Department of Agriculture, Forest Service, Intermountain Research Station.

Parsons, D. J. (2000). The challenge of restoring natural fire to wilderness. In D. N. Cole, S. F. McCool, W. T. Borrie, \& J. O'Loughlin (Comps.), Wilderness Science in a Time of Change Conference, Volume 5: Wilderness ecosystems, threats, and management (pp. 276-82). Proceedings RMRSP-15-Vol-5. Ogden, UT: U.S. Department of Agriculture, Forest Service, Rocky Mountain Research Station.

Parsons, D. J., \& Landres, P. B. (1998). Restoring natural fire to wilderness: How are we doing? In T. L. Pruden \& L. A. Brennan (Eds.), Fire in ecosystem management: Shifting paradigm from suppression to prescription (pp. 366-373). Tall Timbers Fire Ecology Conference Proceedings, No. 20. Tallahassee, FL: Tall Timbers Research Station.

Sherif, C., Sherif, M., \& Nebergall, R. E. (1965). Attitude and attitude change: The social judgment involvement approach. Philadelphia, PA: W.B. Saunders Co. 
Shindler, B. (2007). Public acceptance of wildland fire conditions and fuel reduction practices: Challenges for federal forest managers. In T. C. Daniel, M. Carroll, C. Moseley, and C. Raish (Eds.), People, fire and forests: A synthesis of wildfire social science (pp. 37-54). Corvallis, OR: Oregon State University Press.

Stankey, G. H. (1976). Wilderness fire policy: An investigation of visitor knowledge and beliefs. (Research Paper INT-180). Ogden, UT: U.S. Department of Agriculture, Forest Service, Intermountain Forest and Range Experiment Station.

Watson, A. E., Hendee, J. C., \& Zaglauer, H. P. (1996). Human values and codes of behavior: Changes in Oregon's Eagle Cap Wilderness visitors and their attitudes. Natural Areas fournal, 16, 89-93.

Whitmore, J. G., Borrie, W. T., \& Watson, A. E. (2004). Bob Marshall Wilderness Complex 2004 visitor study. Final report on file at: U.S. Department of Agriculture, Forest Service, Rocky Mountain Research Station, Aldo Leopold Wilderness Research Institute, Missoula, MT. $160 \mathrm{p}$.

Williams, D. R., Roggenbuck, J. W., Patterson, M. E., \& Watson, A. E. (1992). The variability of user-based social impact standards for wilderness management. Forest Science, 38(4), 738756.

U.S. Department of Agriculture, Forest Service. (1978). Forest Service Manual 5100. Washington, DC: U.S. Department of Agriculture, Forest Service.

U.S. Department of Agriculture, Forest Service. (1985). Forest Service Manual 2320, Amendment 93. Washington, DC: U.S. Department of Agriculture, Forest Service. 